\title{
Penyuluhan dengan Multimedia untuk Meningkatkan Pengetahuan tentang Perilaku Hidup Sehat dan Bersih Siswa SMA
}

\author{
Ifa Roifah, Agus Novianto \\ STIKes Bina Sehat PPNI Mojokerto
}

\begin{abstract}
Abtract
Children are future generations which are the most important asset in order to achieve Nation's success to realize it is needed to apply Clean and Healthy Life Behaviors (PHBS) by no smoking, right personal hygiene, regular physical exercise, and no drugs by using multimedia method extension towards students' knowledge of Clean and Healthy Life Behaviors (PHBS) on educational aspect in SMA Negeri 1 Gondang Mojokerto. The research design is used Pre-Experiment, which is applied One-Group Pre-Post Test Design. The populations of students which join School Health Program are 101 students, and the samples are 81 students taken by probability sampling (Simple Random Sampling). The independent variable is extension through multimedia method and the dependent variable is students' knowledge about Clean and Healthy Life Behaviors (PHBS) on educational aspect. The data is taken by the using of puzzle game crosswords form which is use after and before extension. After all of data collected and data processing statistical test followed by Wilcoxon sign test SPSS17, the result showed Asymp.Sig value (2-tailed) of 0.000 and $\alpha$ of 0.05 . Because Asymp.Sig value (2-tailed) $<\alpha 0.05$ then $\mathrm{H} 0$ is rejected and $\mathrm{H} 1$ is accepted, it means that there is an influence using multimedia method extension towards students' knowledge of Clean and Healthy Life Behaviors (PHBS) on educational aspect in SMA Negeri 1 Gondang Mojokero.
\end{abstract}

\section{Keywords : knowledge of Clean and Healthy Life Behaviors (PHBS), multimedia}

\section{Pendahuluan}

Usaha Kesehatan Sekolah (UKS) merupakan upaya pendidikan kesehatan yang dilaksanakan secara perpadu, sadar, berencana, terarah dan bertanggung jawab dalam menanamkan dan menumbuhkan sikap hidup sehat dalam kehidupan peserta didik sehari-hari. kenyataannya pelaksanaan program UKS pada saat ini tidak berjalan dengan baik. Hasil Tim Pembina UKS (2007) Pusat teryata pelaksanaan UKS sampai saat ini dirasakan masih kurang sesuai dengan yang diharapkan. saat ini baru sekitar 30\% SLTP dan SMU di Indonesia yang melaksanakan program UKS. Banyak program-program UKS yang terdapat disekolah berhenti atau macet. Hal ini disebabkan karena kurangnya pemahaman UKS, bahkan program UKS tersebut tidak dihiraukan oleh pihak sekolah (Saryono, 2007).

Jurnal Ilmu Kesehatan Vol.2 No. 2 Mei 2014
Program UKS diharapkan dapat menerapkan dan membiasakan siswa untuk berperilaku hidup bersih dan sehat. Munculnya berbagai penyakit yang sering menyerang anak usia sekolah ternyata umumnya berkaitan dengan PHBS (KEMENKES RI, 2011).

Hasil penelitian (Pramono, 2011) menyebutkan bahwa orang yang memiliki perilaku hidup tidak baik (kebiasaan sebelum makan, kebiasaan minum, kebiasaan buang air kecil, kebiasaan buang air besar dan kebiasaan istirahat) memiliki resiko 3,5 kali lebih besar menderita diare dibandingkan dengan orang yang memiliki PHBS baik. Responden usia lebih dari 10 tahun sebanyak $76,8 \%$ responden belum benar dalam perilaku cuci tangan, dan $28,9 \%$ belum benar dalam perilaku buang air besar. 
Data yang lain menunjukan $23,7 \%$ responden pernah merokok,. 48,2\% kurang aktivitas fisik (berolahraga), dan 93,6\% kurang mengkonsumsi buah dan sayur (Pramono, 2011). Data harian Jawa Pos (Kamis, 02 Mei 2013) bahwa rokok menjadi pintu masuk pertama mengenal narkoba Badan Narkotika Nasional (BNN) mengatakan bahwa penyebaran narkoba menjadi makin mudah karena anak SD juga sudah mulai mencoba-coba menghisap rokok.

Data BNN tahun 2007, kasus pemakaian narkoba oleh pelaku dengan tingkat SD hingga tahun 2007 berjumlah 12.305. Data ini begitu mengkhawatirkan karena seiring dengan meningkatnya kasus narkoba khususnya dikalangan usia muda dan anak-anak, penyebaran HIV/AIDS semakin meningkat dan mengancam. Hampir $50 \%$ penularan HIV/AIDS menggunakan jarum suntik atau narkoba (Badan Narkotika Nasional, 2007).

Hasil penelitian siswa di SMA Negeri 1 Gondang Mojokerto didapatkan 101 rerponden yang mengikuti kegiatan UKS dan sampel 81 hampir semua responden kedalam perilaku hidup bersih dan sehat katagori kurang factor utama kurangnya penyuluhan tentang PHBS tatanan sekolah yang benar seperti : bahaya napza bahaya personal hgyne buruk bahaya malas berolahraga dan bahaya rokok.

Cara mengurangi dampak dari buruknya PHBS, resiko merokok, dan penyalahguaan Narkotika maka perlunya pendidikan kesehatan bagi peserta didik. Pendidikan Kesehatan merupakan salah satu program UKS dimana para warga sekolah diberikan pengetahuan pendidikan kesehatan.

Pendidikan Kesehatan ini bertujuan untuk meningkatkan pengetahuan dan pemahaman warga sekolah tentang bagaimana cara menjaga kebersihan diri (personal hygiene) seperti cara mencuci tangan dan menggosok gigi dengan baik dan benar, menjaga kesehatan diri (personal health) dengan mengikuti kegiatan olahraga dan aktifitas fisik secara teratur, memberikan pengetahuan tentang bahaya dan resiko merokok serta narkoba untuk mengurangi penyebaran HIV/AIDS. Tidak hanya itu, peserta didik juga diberikan penyuluhan dengan menggunakan media-media yang menarik tentang Perilaku Hidup Bersih dan Sehat (PHBS). Sehingga secara mandiri mampu mencegah penyakit, meningkatkan kesehatannya, serta berperan aktif dalam mewujudkan lingkungan sehat (KEMENKES RI, 2011).

Sangat penting bagi pendidik untuk memberikan pelayanan pemeliharaan kesehatan,dengan mengunakan metode penyuluhan melalui multimedia dengan perkembagan zaman multimedia bisa berupa aplikasi permainan video-vidio gambar atau animasi untuk meningkatkan atau mempoermudah pemahaman siswa dengan cara lansung melihat mengunakan layar (LCD) atau computer.

Yudi Munadi (2008) dalam Setyowati (2009) menyebutkan "Multimedia pembelajaran adalah media yang mampu melibatkan banyak indera dan organ tubuh selama proses pembelajaran berlangsung".

Ada beberapa kelebihan penggunaan multimedia presentasi yaitu: (1) Mampu menampilkan objek-objek yang sebenarnya tidak ada secara fisik atau diistilahkan dengan imagery. Secara kognitif pembelajaran dengan menggunakan mental imagery akan meningkatkan retensi siswa dalam mengingat materi-materi pelajaran. (2) Memiliki kemampuan dalam menggabungkan semua unsur media seperti teks, video, animasi, image.

(3) Sesuai dengan modalitas belajarnya terutama bagi mereka yang memiliki tipe visual, auditif, kinestetik atau yang lainnya. (4) Mampu mengembangkan materi pembelajaran terutama membaca dan mendengarkan secara mudah.

Penelitian ini bertujuan untuk mengetahuai pengaruh penyuluhan melalui metode multimedia terhadap 
pengetahuan siswa tentang PHBS tatanan sekolah di SMA Negri 1 Gondang Mojokerto.

\section{Metode Penelitian}

Penelitian menggunakan desain Pra eksperimen (one group pre test - post test design). Penelitian ini adalah penelitian desain yang digunakan untuk meneliti pada satu kelompok dengan melakukan satu kali pengukuran di depan (pre test) sebelum adanya perlakuan (experimental treatment) dan setelah itu dilakukan pengukuran lagi (post test). Dengan kondisi awal diamati maka bisa digunakan untuk mengevaluasi adanya perubahan sesudah perlakuan dengan membandingkan dengan hasil pengamatan sesudah perlakuan (Notoatmodjo, 2012)

\section{Hasil Penelitian}

Diagram 4.1 Distribusi frekuensi pengetahuan siswa sebelum dan sesudah dilakukan penyuluhan Perilaku Hidup Bersih dan Sehat (PHBS) melalui metode Multimedia di SMA Negeri 1 Gondang Mojokerto Tahun 2014.

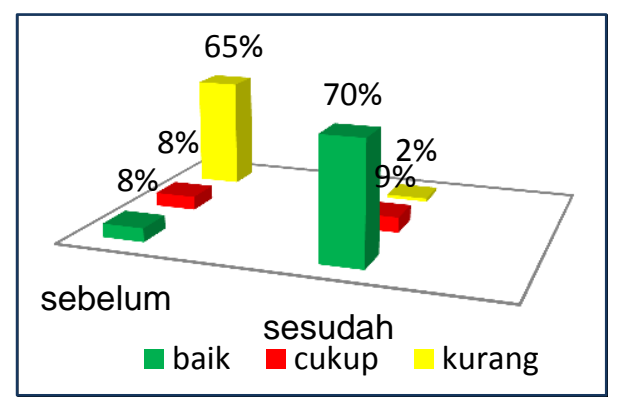

Diagram 4.1 pengetahuan siswa sebelum penyuluhan $65 \%$ kurang dan setelah dilakukan penyuluhan perilaku hidup bersih dan sehat (PHBS) tatanan sekolah $70 \%$ siswa meningkat menjadi baik. Hasil uji wilxoson signed rangks test diperolah hasil $p$ value sebesar 0,00< a0,05 maka Ho ditolak artinya ada pengaruh penyuluhan melalui metode multimedia terhadap pengetahuan siswa tentang perilaku hidup bersih dan sehat
(PHBS) tatanan sekolah di SMA Negeri 1 Gondang Mojokerto.

\section{Pembahasan}

Sebelum diberikan penyuluhan tentang Perilaku Hidup Bersih dan Sehat (PHBS) dapat diketahui bahwa dari 81 sampel penelitian terdapat 65 atau $80,24 \%$ siswa yang pengetahuanya < 56\% dikarnakan siswa kurang mengetahuai tentang perilaku hidup bersih dan sehat (PHBS) dengan benar seperti tidak mengunakan napza personal hygine yang benar, berolahraga teratur dan tidak merokok dalam pengisian game puzlle teka-teki silang (TTS) banyak siswa yang tidak bisa menjawab dikarenakan kurangnya pengetahuan perilaku hidup bersih dan sehat (PHBS) dan ketidak pahaman game puzlle teka-teki silang (TTS).

Setelah dilakukan penyuluhan melalui metode multimedia terhadap pengetahuan siswa tentang perilaku hidup bersih dan sehat (PHBS) 65 atau 80,24\% siswa berpengetauan kurang menjadi 2 atau $2,6 \%$ terjadi adanya perubahan, siswa berpengetahuan cukup dari 8 atau $9,87 \%$ mejadi 9 atau $11,1 \%$ dan berpengetahuan baik dari 8 atau $9,87 \%$ menjadi 70 atau $86,41 \%$.

Menurut Smaldino (2005) dikutip dalam Setyowati (2009) yang menyatakan bahwa Multimedia sistem terdiri dari media tradisional dalam kombinasi atau digabungkan dalam komputer sebagai gambaran teks, gambar, grafik, suara dan video. Istilah multimedia didiskripsikan sebagai penerapan untuk mengkombinasikan berbagai media untuk mempengaruhi tingkat pendidikan. Multimedia merupakan kombinasi dari komputer dan video, atau multimedia merupakan kombinasi dari suara, gambar, dan teks.

Hasil penelitan akhir menunjukkan ada pengaruh penyuluhan melalui metode multimedia terhadap pengetahuan siswa tentang perilaku hidup bersih dan sehat (PHBS) tatanan sekolah di SMA Negeri 1 
Gondang Mojokerto dengan $p$ value 0,000 $<0,05$.

Hasil penelitian ini sejalan dengan dengan hasil penelitian Mochamad Setyo Pramono (2011) menunjukkan bahwa edu-game ini disukai anak-anak. Isi cerita dan warna/gambar dari edu-game merupakan bagian yang paling disukai anak-anak. Terdapat perbedaan yang signifikan antara nilai rata-rata pengetahuan PHBS maupun sebelum dan sesudah perlakuan. Hal ini menunjukkan bahwa edu-game ini cukup efektif untuk digunakan sebagai media bermain dan belajar tentang PHBS siswa .

\section{Simpulan}

1. Hampir seluruh responden kurang memahami bahaya napza, bahaya personal hgyne yang buruk, bahaya malas berolahraga dan bahaya akibat merokok sebelum diberikan penyuluhan.

2. Hamper seluruh responden mempunyai pengetahuan yang baik tentang perilaku hidup bersih dan sehat (PHBS) setelah diberikan penyuluhan.

3. Ada pengaruh penyuluhan mengunakan metode multimedia terhadap pengetahuan siswa tentang perilaku hidup bersih dan sehat (PHBS) tatanan sekolah SMA Negeri 1 Gondang Mojokerto.

\section{Saran}

1. Perlu dilakukan penyuluhan lebih intensif dengan metode multimedia sesuai dengan topic yang trends saat ini.

2. Perlu pengembangan penelitian penyuluhan mengunakan metode multimedia dengan metode yang lain seperti permainan ulartangga yang dimodif dengan PHBS agar para siswa dapat lebih mengetahui pentingnya pola hidup bersih dan sehat (PHBS).
3. Diharapkan bagi siswa saling memberikan informasi tentang bahaya napza bahaya rokok bahaya personal hgyine buruk dan bahaya jika tidak berolahraga teratur.

\section{DAFTAR PUSTAKA}

Arikunto, Suharsimi. 2010. Prosedur Penelitian Suatu Pendekatan Peraktek. Yogyakarta PT Rineka Cipta : Edisi Revisi 2010, 2010.

Citarawati, Yetti Wira. 2009. Media Penyuluhan Artikel. s.1.: 2009, 2009.

Kementrian Kesehatan RI. 2011. Intraksi Suplemen PHBS di sekolah. Jakarta Kemenrian Kesehatan RI : s.n., 2011.11 april 2014

Kementrian Pendidikan dan Kebudayaan . 2013. Modul ield Lab Semester $V$ Keterampilan Pembinaan UKS Kesehatan Jiwa NAPZA dan Ganguan Belajar. Uniersitas Sebelas Maret: s.n., 2013.11 febuari 2014

Kementrian Pendidikan dan Kebudayaan (KEMENDIKBUD UNS). 2013. Modul Field Lab Semester V Perilaku Hidup Bersih dan Sehat (PHBS). Universitas Sebelas Maret: s.n., 2013.11 febuari 2014

Notoatmodjo, $\quad$ Soekidjo. 2012 . Metodologi Penelitian Kesehatan. Jakarta PT RINEKA CIPTA : s.n., 2012.

Pramono, Mochamad Setyo. 2011. s.l. : Buletin Penelitian , 2011, Vol. Vol 39 No 4.7 januari 2014 
Pos, Jawa. Rokok Menjadi Pintu Masuk Pertama Mengenal Narkoba. Jakarta : Jawa Pos.7 januari 2014

RI, Kementrian Kesehatan. 2011. Peraturan Mentri Kesehatan Republik Indonesia Pedoman Pembinaan Perilaku Hidup Bersih dan Sehat (PHBS). Jakarta Kementrian Kesehatan RI: s.n., 2011. nomor 2269/MENKES/PER/X/2011.11 april 2014

Setyowati, ida \& hasim khoirul. 2009. Intructional media. STKIP PGRI JOMBANG : s.n., 2009.

Saryono. 2007. Pelaksanaan Trias Usaha Kesehatan Sekolah di Sekolah Menengah Pertamadi Wilayah Kecamatan Purwokerto Kabupaten Banyumas. Jurnal Keperawatan Soedirman : Universitas Jendral Soedirman.23 maret 2014

Sugiyono. 2011. Metode Penelitian Kesehatan (Pendekatan Kuantitatif Kualitatif dan R\&D). Bandung Alfabeta : $\quad$ s.n., 2011. 